\title{
K. Fokt
}

\section{SLAVIC ETHNOPOLITIES:}

\section{A FEW REMARKS ON THE «TRIBAL QUESTION» AS ANSWER TO THE QUESTIONNAIRE OF «STUDIA SLAVICA ET BALCANICA PETROPOLITANA»}

The questions raised by the Editors of «Studia Slavica et Balcanica Petropolitana», concerning the character of early medieval Slavic tribes, are extremely important and the method of a questionnaire seems very adequate to revive and boost the scholarly discussion on that crucial topic. In face of the variety of methodological orientations and scholarly traditions in different Slavic as well as non-Slavic countries it would be of crucial importance to try to bring those traditions together in order to prepare some common platform for further disputes and at least an attempt of common vocabulary describing the past realities. In the few following paragraphs, I will try to answer shortly the questions kindly sent to me by the Editors, basing mostly on my knowledge of the Western Slavdom, hoping for reaction from the Colleagues from other countries.

Do you use the term «tribe» in your work when dealing with early medieval Slavic societies? If you do, please tell us in what contexts and with what purpose you prefer to use the term.

I am using the term «tribe» in my papers without quotation mark — remaining, however, aware of its conventional character ${ }^{1}$. This term - in Polish «plemię» — in the Central European scholarship denotes usually all groups of people that were denoted with a common

${ }^{1}$ Cff here: Fokt K. Między Pragą a Miśnią: o lokalizacji Pobarane i Trebouane raz jeszcze // Śląski Kwartalnik Historyczny Sobótka. 2014. Vol. 69/1. P. 4-5.

(C) K. Fokt, 2016 
name, which at least could have funcioned as an ethnonym, were endowed with some portion of cohesion and autonomy against external subjects and were not one of the dynasty-based polities which evolved into early states. It is, therefore, more like a useful metaphor than a really operational scholarly term, as it contains various sorts of social structures, among those the ones which could have evolved into an early state but did not manage to. Moreover, such a meaning of the term «tribe» contrasts sharply with its usage in cultural anthropology. Despite all that, in my opinion, for today - concerning the long tradition of such a conventional use of the term «tribe» - there is no other solution than to remain by using this imperfect concept. One cannot deny that quite different sorts of communities, organized in various way - tribes sensu strictiori (as defined in cultural anthropology), chiefdoms, ethnarchies (e. g., the Stodorans or Obodrites, ruled by their dynasties of dukes) or even some tribe-like creations of early states (as Dasane and Liutomerici in the famous «Prague charter» from the year 973/1086), would correspond with the very low conditions of such a broad definition. There is, however, no other choice left for today than to use the term «tribe» in metaphorical sense, because the chronicles and charters of the early Middle Ages extremely rarely enable us to state anything more about the entities called in the historiographies «tribes» and in the sources themselves - mostly just by thir names. Thus, the term «tribe» can be, in my opinion, applied to the historical realities, but only as a conventionalized metaphor.

Do you consider it appropriate to use the term «tribe» when referring to the ethnic history of the Slavs in the early Middle Ages? If you do, please explain what you mean by the term «tribe» in its ethnic sense. If not, please tell us why.

The above sketched definition of a tribe - group of people called by common name which could be an ethnonym, appearing in the sources as subject of political and/or military activities, which cannot be, however, identified with any of the predatory dynasty-based polities which evolved into states - implicates the understanding of tribes not as ethnic groups only, but rather as ethnopolities, i. e. entities embracing ethnic and political components at the same time. It probably reflects the actual state of affairs in the early Middle Ages. Only the framework of a large dynastic polity, containing a few tribal territories and identities but no autonomous tribal political structures, would allow to approach the ethnic and political identities separately ${ }^{2}$. That is why the tribes of the early Middle Ages should be always treated as ethnopolities, not ethnic groups, and as such they were mentioned in the sources ${ }^{3}$.

Do you consider it appropriate to use the term «tribe» when referring to the social and political history of the Slavs in the early Middle Ages? If you do, please explain what you mean by the term «tribe» in its social sense. If not, please tell us why.

The answer to this question has been already given in the paragraphs above: the term «tribe» is in fact widely used in a metaphorical sense, actually as a synonym of the term «people», and for today there are no prospects of changing this situation. As was also mentioned above, there could have been many different variations of social structures behind the conventionally used term «tribe». The only certain common feature of such ethnopolities would be their visibility for the authors of early medieval historical accounts as groups of people acting together, having some political constitution and military organization existing

\footnotetext{
${ }^{2}$ Even such polities, however, tended to produce ethnic identities and narratives — it was probably a conditio sine qua non of their consistency and long lasting.

${ }^{3}$ Cf.: Třeštík D. Počátky Přemyslovců. Vstup Čechů do dějin (530-935). Praha, 2008. P. 59-60.
} 
behind a common name, that were not yet dominated by a dynasty ${ }^{4}$. With such preconditions, e. g., the Obodrites (roughly until Henry son of Gottschalk, rex Slavorum) and Stodorans would be justly called tribes in spite of being lead by their dynasties of rulers - as long as for the outer sources the peoples, not solely the dukes, were identified as subjects of political and military activity (their rulers could be called «ethnarchs», leaders of the peoples, and not monarchs, rulers per se). On the other hand, Poland or Rus' should not be treated as tribal names, being secondary products of integrating activities of the expansive political structures centered around the clans of rulers (Piasts and Riurikids).

What, in your opinion, were the basic social mechanisms ensuring the dissemination and reproduction of group («tribal») identities within Slavic-speaking communities of the early Middle Ages? Did those mechanisms differ from those functioning within the Germanic world?

These mechanisms probably did not differ from the ones known from the Germanic world - as reconstructed by Reinhard Wenskus and the Vienna school. This conviction is based upon the premise that the Slavs were a part of the milieu of the European Barbaricum, sharing common features with other peoples living beyond the ancient borders of the Empire . $^{5}$ This general view, however, must be supplemented with some more precise studies of specific areas. For example, in the Western Slavic territory at least four zones may be distinguished: the «limes» zone, neighboring directly with the Avars and Francs, the transition zone (from the limes to the interior), the interior and the maritime zone. In the «limes» zone, the «primary» tribes of the migration period evolved into huge units — called by Dušan Třeštík (according to the German use of the word), gentes - some of which (Obodrites, Velets, Serbs, Czechs) bore archaic ethnonyms and got subdivided into lower-class entities. In relation to this zone an important question, to which I don't know proper answer, would be which level - the lower or higher - should be denoted with the term «tribe», or maybe whether instead, small and big tribes ought to be distinguished (as has been practiced e. g. by H. Łowmiański). No matter how antiquated it looks like, the proposal involving the division into big and small tribes seems the most suitable here. The socio-political reality was fluent and there are no criteria which would allow to restrict the term «tribe» exclusively either to the upper or to the lower level, as entities of both those levels could have been in certain regions and periods classified as tribes in the above described, metaphorical sense. Moreover, probably the ethnopolities functioned on both those levels simultaneously (as by Obodrites, Serbs, Bohemians), only their interrelations were changing ${ }^{6}$. Further on, there was a transition zone, with tribes - more (e. g. Stodoranie, Głomacze, Milczanie, Ślężanie) or less (e. g. Bobrzanie, Trzebowianie, Wiślanie) stable, but only slight traces of old ethnonyms and subdivision into two levels (altera Chrowati in Upper Silesia). Moreover, it seems possible that the tribes in the transition zone were being created only in the late $8^{\text {th }}-10^{\text {th }}$ centuries, which would be contemporary with the oldest archaeological traces of dynamization and militarization of local societies (building of strongholds, findings of weapons) and the extension of the

${ }^{4}$ Cf.: Łowmiański H. Początki Polski. Z dziejów słowian w I tysiącleciu n. e. Vol. IV. Warszawa, 1970. P. 267-269 (remarks on the status of Liudewit).

${ }^{5}$ Cf. here: Modzelewski K. Barbarian Europe. Frankfurt am Main, etc., 2015.

${ }^{6}$ E. g. the Serbs under Derwan or Miliduch were acting — as far as we may draw conclusions from scarce sources - as a whole, and in some moment in the $9^{\text {th }}$ century one of their lower-level tribes, Colodici, played important role as such under its own name and not as a part of the Serbs. 
influence of the Francs; in fact, at least in some areas of that zone (e. g., most of Upper Lusatia) this could have been the moment of the actual Slavic colonization. Further in the interior (main body of the present inland Polish territory) there were no discernible tribes at all until the creation of the Piast state and for a long time also no special archaeological traces of dynamization of society (finds of silver, weapons, etc.). No traces of tribes were also registered in the maritime zone despite rather early and numerous traces of militarization and dynamization of societies, reflected in the archeological materials ${ }^{7}$. It seems, therefore, that we may be dealing with four types of social organizations: 1) tribes of older descent, existing and evolving all the time in the limes zone, 2) presumed segmentary societies of the interior which never managed to form tribes or chiefdoms before they were conquered by the Piasts, 3 ) tribes of the transition zone, which were formed with no significant relation to the old ethnonymy ${ }^{8}$ - probably not ex nihilo, but rather using some patterns well known in places of their origin (which was, at least partially, the «limes» zone), 4) areas organized politically without tribes (the maritime zone). As the whole development of the Western Slavdom ran probably from the limes area (from where the oldest finds - the Prague type - are known) towards the interior and the Baltic Sea, one must assume that the Slavs moving east- and northwards were - so to say — «forgetting» the idea of tribal ethnopolitical organization. It seems that it was most useful for them only in the borderland where they were in contact with dangerous neighbors. One must, therefore, accept the phenomenon of secondary development of tribes in the interior of the Western Slavdom - it seems, however, that simultaneously also not tribes but local principalities evolved there (the initial polity of the Piast dynasty was probably one of them).

What, in your opinion, was the interrelation between kinship and territoriality principles of social and political organization of Slavic communities, which used to be called tribes in historiography, in the $7^{\text {th }}$ and $8^{\text {th }}$ and, later, in the $9^{\text {th }}$ and $10^{\text {th }}$ centuries? What, in your opinion, was the role of warrior retinue elements in the formation of communities usually called tribes?

I don't suppose that the sources we have allow us to solve such issues. It seems, however, that — just as V. Procházka has stated more than half a century ago — indeed, the earlier, more «ethnic», and the later, «territorialized» periods in the history of the Slavic tribes may be discerned ${ }^{9}$. Probably on both stages organized groups of warriors ${ }^{10}$, constituting some «tradition cores» and military power at the same time, were important for creation of tribes as ethnopolities. However, a tribe of the earlier period probably looked more as a «wandering

${ }^{7}$ It seems similar to the situation in Scandinavia, as was aptly pointed out by Przemysław Urbańczyk (Urbańczyk P. Trudne początki Polski. Wrocław, 2008. P. 105).

${ }^{8}$ The names of those tribes are rather related to local oro- and hydronyms (e. g. Ślężanie, Bieżuńczanie, Bobrzanie) or topography (Opolanie, Trzebowianie), sometimes they are patronymic (Gołęszyce, Dziadoszyce), generally, however, altera Chrowati (probably in Upper Silesia) would be the only trace of the older ethnonyms, connected with the Migration Period and the Avar Khaganate, which survived in the «limes» area, also in the western Balcan and Alps regions (Croats, Serbs, Czechs, Obodrites).

${ }^{9}$ See: Procházka $V$. 1) Organisace kultu a kmenove zřízení polabsko-pobaltských Slovanů // Vznik a Počatky Slovanů. 1958. Vol. 2. P. 146-147; 2) Tipologičeskij očerk dogosudarstvennoj političeskoj organizašcii Slavjan // VI Mezinarodni Sjezd Slavistů v Praze. Resume přednašek, přispěvků a sdeleni. Praha, 1968. P. 409.

${ }^{10}$ I would not like to use the specialized term «retinue» in this context, as we know too little about the details of the social and political organization of Slavs in the $1^{\text {st }}$ millenium AD. 
army» while in the later period there were more stable territories in which the identities were built upon.

What, in your view, was the Slavic community in the $7^{\text {th }}$ and $8^{\text {th }}$ and, later, in the $9^{\text {th }}$ and $10^{\text {th }}$ centuries? Can it be defined as an ethnic community? What, in your opinion, were the social mechanisms responsible for the distribution and reproduction of the Slavic group identity in the early Middle Ages?

The Slavic community - because of the existence of a really common name for different peoples and far reaching linguistic uniformity - was probably more real than the Germanic community, which is actually a historiographical construct basing upon illegitimate identification of ethnic and linguistic realities. In fact, however, it is not obvious whether the Slavs could have been a real ethnic entity — i. e., community with clear notion of identity. For example, the sources do not allow to state whether the ethnogenetic myths of Slavs (pieces of which are known from the Bavarian Geographer and the account of al-Mas'udi) were embracing all of them or, as it was the case with the Mannus-myth of the Western Germanic peoples, only some of the peoples that were, in linguistic sense, Slavs. It is, therefore, hard to say what social mechanisms could be responsible for the spreading of the Slavic identity as we actually do not know what form such an identity had and how deep- and far-reaching it was. Nevertheless, the existence of the historical, not historiographic term denoting all the Slavs and high degree of their linguistic closeness until the $12^{\text {th }}$ century suggest that some Slavic common identity should have existed - we don't know, however, how broad it spread and how deep penetrated into the identities of particular persons and groups.

\section{Данные о статье}

Автор: Фокт, Кшиштоф — доктор археологии, Ягеллонский университет, Краков, Польша, krzysztof. fokt@uj.edu.pl

Заголовок: Славянские этнополитические организмы: Несколько замечаний о «племенном вопросе» в качестве ответов на вопросы журнала «Studia Slavica et Balcanica Petropolitana»

Резюме: В статье предпринята попытка ответить на вопросы о славянских «племенах», поднятые журналом «Studia Slavica et Balcanica Petropolitana», сфокусировав при этом внимание на западных славянах. Автор исходит из того, что в настоящее время нет ни одного определения славянского племени, которое бы прямо соответствовало реалиям прошлого. Из-за скудости источников мы вынуждены вместо этого использовать условные термины. При этом термин «племя» применительно к западным славянам de facto используется как синоним понятий «этнос» или «народ». Вследствие этого почти каждая социальная единица, обладавшая каким-либо общим названием, которое может пониматься как этноним (за исключением лишь больших династических политий, эволюционировавших в конце концов в ранние государства) может в современной польской, чешской или немецкой науке именоваться «племенем». В статье также предпринята попытка разделить западное славянство на четыре отдельные зоны, представлявшие различные модели этнополитических структур: зону «лимеса» (где находились «gentes», сопоставимые с другими гентильными организмами поздней античности и раннего Средневековья), внутреннюю зону (где находились по преимуществу сегментированные общества, не проявлявшие заметной активности в военном деле и торговле и долгое время остававшиеся «невидимыми» авторам дошедших до нас источников в качестве этнополитических структур), приморскую зону (рано вовлеченную в торговлю и военное дело, но не разделенную, насколько нам известно, на «народы»/«племена»), а также переходную зону между областями «лимеса» и внутренними территориями (охватывавшую Лужицы и левобережную Силезию).

Ключевые слова: славяне, западные славяне, этническая идентичность, политические структуры, племя 
Information about the article

Author: Fokt, Krzysztof - Doctor of Humanities (Ph. D. in Archeology), Poland, Cracow, Jagiellonian University, krzysztof.fokt@uj.edu.pl

Title: Slavic Ethnopolities: A few Remarks on the «Tribal Question» as Answer to the Questionnaire of «Studia Slavica et Balcanica Petropolitana»

Summary: The texts attempts to answer the questions raised by the Editors of «Studia Slavica et Balcanica Petropolitana» in their questionnaire, focusing on the Western Slavdom. The main assumptions of the paper is that there is no definition of Slavic tribe that would correspond directly with the past reality. Due to the scarcity of sources we are condemned to use some conventionalized terms instead and that is how the term «tribe» functions for the Western Slavdom: as de facto synonym of the notions of «ethnos» or «people». Therefore, almost every social group which had some common name that could have been comprehended as an ethnonym - only apart from the huge dynastic polities which finally evolved into early states - may be called a «tribe» in the present Polish, Czech or German scholarship. In the paper, attempts were made also to divide the Western Slavdom into four distinctive zones representing various patterns of ethnopolitical structures: the «limes» zone (filled with gentes comparable to other gentile peoples of late Antiquity and early Middle Ages), the interior (dominated probably by some segmentary societies being not very active in warfare and trade and for a long time remaining «invisible» for the sources as ethnopolitical structures), the maritime area (early active in trade and warfare but not divided — as far as we know — into peoples/tribes) and the transition zone between the «limes» and interior areas (embracing both Lusatias and the left-bank Silesia).

Keywords: Slavs, Western Slavdom, ethnic identity, political structures, tribe

$$
\text { References }
$$

Fokt, Krzysztof. Między Pragą a Miśnią: o lokalizacji Pobarane i Trebouane raz jeszcze [Between Prague and Meissen: Once again on the localization of the Pobarane i Trebouane], in Ślaski Kwartalnik Historyczny Sobótka. 2014. Vol. 69. No. 1. P. 3-21 (in Polish).

Łowmiański, Henryk. Początki Polski. Z dziejów słowian w I tysiącleciu n. e. [The beginnings of Poland. From the history of the Slavs in the $1^{\text {st }}$ millenium A. D.]. Vol. IV. Warszawa: Państwowe wydawnictwo naukowe, 1970. 538 p. (in Polish).

Třeštík, Dušan. Počátky Přemyslovců. Vstup Čechů do dějin (530-935) [The beginnings of the Přemyslids. The entry of the Czechs into history]. Praha: Nakladatelství Lidové noviny, 2008. 658 p. (in Czech).

Modzelewski, Karol. Barbarian Europe. Translated by Ewa Macura; editorial work by Elena Rozbicka. Frankfurt am Main, etc.: Peter Lang, 2015. 414 p.

Procházka, Vladimír. Organisace kultu a kmenove zř́zení polabsko-pobaltských Slovanů [The organization of the cult and tribal system of the Polabian-Baltic Slavs], in Vznik a Počatky Slovanů. 1958. Vol. 2. P. 145-167 (in Czech).

Procházka Vladimír. Tipologičeskij očerk dogosudarstvennoj političeskoj organizašcii Slavjan [Typological essay on the pre-state political organization of the Slavs], in VI Mezinarodni Sjezd Slavistù v Praze. Resume přednašek, přispěvkủ a sdeleni. Praha, 1968. P. 409 (in Russian).

Urbańczyk, Przemysław. Trudne początki Polski [Difficult beginnings of Poland]. Wrocław: Wydawnictwo Uniwersytetu Wrocławskiego, 2008. 420 p. (in Polish). 